Volume 13

Issue 3 Critical Genocide and Atrocity

Prevention Studies

$12-20-2019$

\title{
Book Review: Rejoinder: Anthropology, Critique, and Justice in Translation
}

Alexander Hinton

Rutgers University

Follow this and additional works at: https://digitalcommons.usf.edu/gsp

\section{Recommended Citation}

Hinton, Alexander (2019) "Book Review: Rejoinder: Anthropology, Critique, and Justice in Translation," Genocide Studies and Prevention: An International Journal: Vol. 13: Iss. 3: 173-175.

DOI:

https://doi.org/10.5038/1911-9933.13.3.1714

Available at: https://digitalcommons.usf.edu/gsp/vol13/iss3/17

This Book Review is brought to you for free and open access by the Open Access Journals at Digital Commons @ University of South Florida. It has been accepted for inclusion in Genocide Studies and Prevention: An International Journal by an authorized editor of Digital Commons @ University of South Florida. For more information, please contact digitalcommons@usf.edu. 


\section{Book Review: Rejoinder: Anthropology, Critique, and Justice in Translation}

\section{Acknowledgements}

I'd like to thank Sabbah Carrim and Timothy Williams for their thoughtful reviews and the book editors of Genocide Studies and Prevention, JoAnn DiGeorgio-Lutz and Brian Kritz, for putting together this book forum. I'd also like to thank Nicole Cooley for her comments on my essay. 


\title{
Book Review Forum Rejoinder: Anthropology, Critique, and Justice in Translation ${ }^{1}$
}

\author{
Alexander Laban Hinton \\ Rutgers University \\ Newark, New Jersey, USA
}

Man or Monster?: The Trial of a Khmer Rouge Torturer

Alexander Laban Hinton

Durham, Duke University Press, 2016

360 Pages; Price: \$28.95 Paperback

The Justice Facade: Trials of Transition in Cambodia

Alexander Laban Hinton

Oxford, Oxford University Press, 2018

304 Pages; Price: \$32.95 Paperback

Doppelgänger. I begin with a confession. The Justice Facade is Man or Monster?'s double. ${ }^{2}$ Companion volumes. They stand alone, but each haunts the other. Sabah Carrim and Timothy Williams are ideal reviewers in this regard, each having written thoughtful reviews of Man or Monster?, the first-born of these fraternal twins. ${ }^{3}$ Not surprisingly, their reviews directly and indirectly point to the parentage, anthropology and critique manifest in critical genocide and transitional justice studies form. ${ }^{4}$

Carrim and Williams are both political scientists who have done research on the Khmer Rouge Tribunal. But Carrim (law, human rights, and creative writing) and Williams (transitional justice and perpetrator studies) also have sub-disciplinary foci and areas of expertise that lead them to highlight key themes of The Justice Facade and its relation to Man or Monster? in different ways.

Both, for example, note the emphasis on critique. Carrim does so in her first sentence through literary allusion, quoting the novelist Louis Ferdinand Céline, who states "Everything that's important goes on in the darkness." This quote indeed speaks to a key aim of both projects: unpacking taken-for-granted assumptions and common-sense knowledge and looking at what has thereby been occluded.

Man or Monster? takes up these issues in terms of the notions of articulation, redaction, the redactic, dehiscence, thick frames of power, and the banality of everyday thought. ${ }^{5}$ The Justice Facade, in turn, invokes these conceptual ideas but inflects them through the idea of the transitional justice imaginary and related metaphor of the justice facade.

And indeed, returning to Carrim's invocation of Céline, we might say that both projects argue for the important of looking at "the darkness" masked by the facade of presumption and the thick frames of power, ranging from the torture chamber to transitional justice. The Justice Facade

\footnotetext{
${ }^{1}$ Professor Hinton's rejoinder to the book reviews by Carrim and Willams should have been published in the same issue as part of a book review forum in 13(2) of the journal. We apologize for the editorial delay and present his complete rejoinder in this issue.

${ }^{2}$ Alexander Laban Hinton, Man or Monster? The Trial of a Khmer Rouge Torturer (Durham, NC: Duke University Press, 2016); see also Timothy Williams, “Book Review: The Justice Façade: Trials of Transition in Cambodia," Genocide Studies and Prevention: An International Journal 13, no. 2 (2019), 152-154; Sabah Carrim, "Book Review: The Justice Façade: The Trials of Transition in Cambodia," Genocide Studies and Prevention: An International Journal 13, no. 2 (2019), 155-158.

${ }^{3}$ Sabah Carrim, "Book Review: Man or Monster? The Trial of a Khmer Rouge Torturer," Social \& Legal Studies 27, no 4, (2018), 529-542; Timothy Williams, "Book Review: Man or Monster? The Trial of a Khmer Rouge Torturer," Genocide Studies and Prevention: An International Journal 10, no. 3 (2016), 98-100.

${ }^{4}$ Alexander Laban Hinton, "Critical Genocide Studies," Genocide Studies and Prevention: An International Journal 7, no. 1 (2012), 4-15.

${ }^{5}$ For a detailed discussion of "the banality of everyday thought" in relationship to Arendt's "banality of evil," see Sabah Carrim, "The Legacy of Hannah Arendt's Banality of Evil," Review of Human Rights 3, no. 1 (2018), 43-64. Her discussion of the banality of everyday thought bears directly on The Justice Facade's discussion of the transitional justice imaginary among other things.
} 
delineates this transitional justice imaginary in detail, highlighting its key assumptions, aspects, and obfuscations.

Williams likewise notes The Justice Facade's focus on critique, locating the book within a larger "critical turn" in human rights and transitional justice - and I would add peace and conflict studies and critical genocide and prevention studies. ${ }^{6} \mathrm{He}$ also notes the connection to power, an issue explored in detail in both books through, for example, discussion of the "thick frames of power" (Man or Monster?) and a "discursively-informed phenomenological transitional justice" and the masking and obfuscating effects of the transitional justice imaginary and facade (The Justice Facade).

What, exactly, is being masked? This point is suggested from the start by each book's cover image. The cover of Man or Monster? highlights articulation and redaction with a defaced photo of Duch, the commandant of S-21 prison, which is graffitied in Khmer and English vernaculars, opaque to non-speakers, which diverge in critical ways.
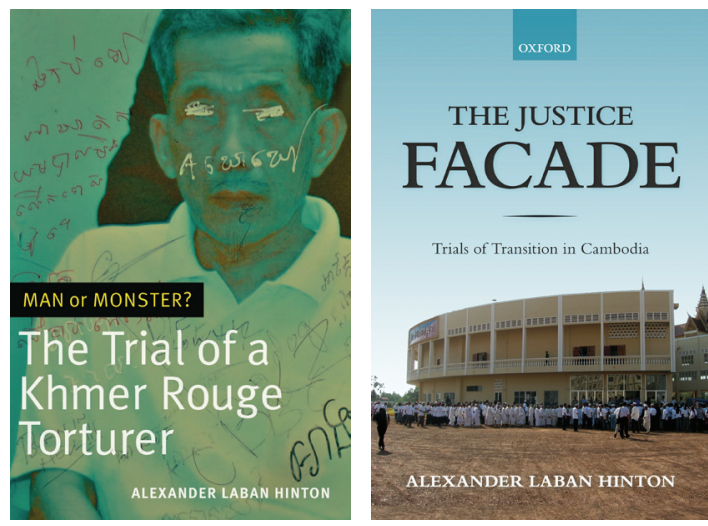

Likewise, The Justice Facade's cover features the not yet complete "modern" ECCC court, a project under construction. The blue skies rise above, suggesting aspiration for a higher, even utopian, purpose. Behind the court "facade" stands a hardly noticeable building featuring "traditional" Khmer architectural style hinting at something "local" that is obscured. Likewise, a line of Buddhist "nuns," dressed in white, stand in front of the court, also barely distinguishable yet also suggestive in this regard.

Here we segue to the second background strand of the companion volumes' parentage, anthropology. Again, Carrim and Williams discuss this issue in different ways. Williams points to my anthropological approach directly, while also noting in passing that The Justice Facade argues for a discursively-informed phenomenological approach to transitional justice. This phenomenological approach is one area that perhaps could have been taken up in more detail by these two fine reviews and one that inflects more broadly.

And indeed, The Justice Facade directly critiques of universalizing approaches that often dominate not just transitional justice but human rights, development studies, genocide studies, peace and conflict studies, and a range of related and normatively tinged disciplines. As Williams notes, the direct critique of Sikkink's notion of "the justice cascade" is one way the book does this. But The Justice Facade does so in other ways large and small, building up a broad case that the transitional justice imaginary obfuscates and misdirects us in many ways, not just in obscuring the centrality of Buddhism to how many Cambodians experience and understand transitional justice but also how power and interests are involved and influence the court. Carrim and Williams touch on temporality -- ranging from teleological assumptions to the jurisdiction of the court, which delimits and narrows "the truth" - as an illustration of this point.

Both reviewers also highlight other ways in which The Justice Facade (with many of echoes of Man or Monster? starting with its graffitied cover) offers not just a critique of transitional justice but

${ }^{6}$ Hinton, Critical Genocide Studies, 4-15. 
an argument for and illustration of how transitional justice and international law could benefit from being anthropologically and ethnographically informed and more experience-near. Otherwise, transitional justice risks remaining suspended in the transitional justice imaginary, a point made at the onset in the The Justice Facade's framing preface.

A phenomenological approach, The Justice Facade argues, offers much in this regard. On the one hand, it provides a theoretical and conceptual means of escaping lingering transitional justice dilemmas such as essentialism, the local-global binary, and "thin" models of "localization." To step behind the transitional justice facade, Carrim and Williams both note, we must take account of the intertwined discourses and enactments of transitional justice in contexts ranging from the court itself to rural villages where the mediating influence of Buddhism is extremely important.

Both reviewers point out that the volume raises important issues regarding this process of vernacularization. ${ }^{7}$ And indeed, the title I almost chose for this book is "Justice in Translation." It is only through an understanding of everyday experience, understandings, and practice, The Justice Facade contends, that we can begin to answer the question with which the book begins: "What is the point of holding international tribunals in places like Cambodia."

To close, I want to raise one last issue: writing. The Justice Facade and especially Man or Monster? seek to offer both critique and insight through literary strategies - an issue I have discussed in detail in a 2018 Journal of Genocide Research book forum review on Man or Monster?.

This use of literary strategies is most evident in The Justice Facade's Preface, which immediately foregrounds the transitional justice imaginary through a story. The book later uses life-history, narrative structure, and person-centered accounts that decenter the explanatory and directive prose that often dominates our discipline. Indeed, both The Justice Facade and Man or Monster? use literary strategies to subvert the teleology that often seeps into our hyper-directed exposition. Carrim, who is also a novelist, is keenly aware of such strategies.

So perhaps it is appropriate to conclude with thanks to Carrim and Williams for their thoughtful review essays and the ways they point out how The Justice Facade, in indirect conversation with its Man or Monster? doppelgänger, explores what is lost "in the darkness." This endeavor, as Carrim highlights, is at the heart of both books and, I would add, a critical genocide (and transitional justice) studies.

\section{Acknowledgements}

I'd like to thank Sabbah Carrim and Timothy Williams for their thoughtful reviews and the book editors of Genocide Studies and Prevention, JoAnn DiGeorgio-Lutz and Brian Kritz, for putting together this book forum. I'd also like to thank Nicole Cooley for her comments on my essay.

\footnotetext{
${ }^{7}$ For a broader discussion of vernacularization, see Petty Levitt and Sally Merry, "Vernacularization on the Ground: Local Uses of Global Women's Rights in Peru, China, India and the United States," Global Networks 9, no. 4 (2009), 44-161.

${ }^{8}$ See also my rejoinder to the forum reviews, which also sought to use literary strategies: Alexander Laban Hinton, "Postscript - Man or Monster?" Journal of Genocide Research 20, no. 1 (2018), 181-192. This aspect of these companion volumes has also been discussed in detail by other book reviewers, such as: Catherine Bolton, "Book Review: Man or Monster? The Trial of a Khmer Rogue Torturer," American Anthropologist, 120, no. 1 (2018), 176-177; and Rachel Hughes, "Book Review: Man or Monster? The Trial of a Khmer Rouge Torturer," Law \& Society Review, 52, no. 2 (2018), 543-546.
} 